Sains Malaysiana 50(12)(2021): 3683-3691

http://doi.org/10.17576/jsm-2021-5012-18

\title{
A Randomized Controlled Trial on the Effect of VCO in Reducing Glucose and Body Weight in Post-Acute Coronary Syndrome Patients: A Pilot Study
}

(Ujian Terkawal Rawak terhadap Kesan VCO dalam Mengurangkan Glukosa dan Berat Badan pada Pesakit Sindrom Koronari Pascaakut: Suatu Kajian Perintis)

\author{
Sharifah Shafinaz binti Sh Abdullah, Mei Chan Chong*, Khatijah Lim Abdullah, Imran Zainal \\ ABIDIN \& BEE WAH YAP
}

\section{ABSTRACT}

The aims of this paper were to determine the effect of virgin coconut oil (VCO) on bodyweight and serum glucose level among acute coronary syndrome (ACS) patients. Various clinical trials on animal studies have found that the VCO has many beneficial effects on health. However, there have been limited published human studies on the pharmacological properties of VCO. Investigation on human subjects is extremely required in order to provide more empirical evidence to show the effect of VCO for ACS patients. Randomised single blind study conducted between March 2018 and April 2018. RCT was conducted among 70 ACS patients for 30 days. Participants in group A received their bottles containing 100 pieces of virgin coconut oil soft gels and were required to ingest 10 capsules per day $(5 \mathrm{~mL} / 5 \mathrm{gm})$ and continue routine treatment (diabetic diet and diabetic medication). Group B participants continued receiving routine treatment. Changes in serum fating blood sugar and body weight were identified using a paired t-test and independent t-test. A total of 70 patients participated with ages of 51 years old and older and were mostly male. The serum FBS and body weight of the intervention group that received VCO were reduced about 13.6\% on day 30, from the baseline on day 1 . They also had body weight reduction of about $2 \%$ with p value of less than 0.05 . In contrast, the control group that only received routine treatment showed an increment of $12.1 \%$ in their serum FBS and had no changes in body weight. These reductions were noted within 30 days of consuming a daily dose of VCO (5 g every day). The properties of lauric acid and antioxidants present in the VCO composition were key players in the reduction of serum glucose levels and body weight. VCO can reduce serum glucose levels and body weight with $5 \mathrm{~mL}(5 \mathrm{~g})$ of VCO per day for 30 days. Also, VCO may have a positive effect towards the glucose level and other cardiovascular risk factors.

Keywords: Acute coronary syndrome; diabetes mellitus; medium chain triglyceride; virgin coconut oil

\section{ABSTRAK}

Kajian ini bertujuan untuk melihat keberkesanan minyak kelapa dara ke atas serum glukosa dan berat badan dalam kalangan pesakit sindrom koronari akut (SKA). Kajian ke atas haiwan mendapati minyak kelapa dara mempunyai beberapa kesan kepada kesihatan. Walau bagaimanapun, kajian keberkesanan minyak kelapa dara ke atas manusia adalah terhad. Penyelidikan keberkesanan minyak kelapa dara terhadap manusia adalah diperlukan untuk menyediakan lebih bukti empirik terhadap kesan minyak kelapa dara kepada pesakit SKA. Ujian terkawal rawak buta tunggal telah dijalankan pada Mac 2018 sehingga April 2018. RCT telah dijalankan ke atas 70 orang pesakit SKA selama 30 hari. Peserta daripada kumpulan A telah diberi satu botol yang mengandungi 100 biji kapsul minyak kelapa dara dan perlu mengambil 10 kapsul sehari $(5 \mathrm{~mL} / 5 \mathrm{gm})$ serta meneruskan rutin perawatan (diet dan ubat diabetik). Peserta daripada kumpulan B pula meneruskan rutin perawatan seperti biasa. Perubahan pada serum glukosa dan berat badan dikenal pasti dengan menggunakan analisis ujian t berpasangan dan ujian t tak bersandar. Seramai 70 peserta kajian kebanyakannya terdiri daripada peserta lelaki dan berusia dalam lingkungan 51 tahun dan lebih. Perbandingan serum glukosa daripada kumpulan intervensi menampakkan penurunan dari hari pertama kajian sehingga hari ke 30 sebanyak $13.6 \%$ dan penurunan berat badan adalah sebanyak $2 \%$, dengan kadar signifikasi kurang daripada 0.05. Kumpulan yang menerima penjagaan rutin menunjukkan peningkatan serum FBS sebanyak 12.1\% dan tiada perubahan dalam berat badan. Penurunan ini dapat dilihat pada hari ke 30 dengan pengambilan VCO sebanyak 5 g sehari. Kesan penurunan glukosa dan berat badan adalah disebabkan oleh tindakan asid laurik dan antioksida yang terdapat di dalam komposisi VCO. Minyak kelapa dara menunjukkan keupayaan menurunkan serum glukosa dan berat badan dengan dos $5 \mathrm{~mL} / 5 \mathrm{gm}$ sehari selama 30 hari. Minyak kelapa dara mempunyai kesan positif terhadap serum glukosa dan faktor risiko kardiovaskular yang lain.

Kata kunci: Diabetes mellitus; minyak kelapa dara; sindrom koronari akut; trigliserida rantai sederhana 


\section{INTRODUCTION}

The Ministry of Health Malaysia (MOH) estimated that $73 \%$ of Malaysians die from non-communicable diseases and diabetes mellitus was one of them (Ahmad 2016; MOH 2015). Acute Coronary Syndrome (ACS) has been proven to be resulted from accumulation of lipids in the intima layer of the coronary arteries. This disease, which is known as atherosclerosis causes narrowing in the arteries and hence, preventing the blood supply to myocardium. The myocardium when deprived of oxygen and nutrition will cause the patient to suffer from myocardium infarction (Barstow et al. 2017). In Malaysia, ACS is one of the leading causes of death for many years (Ahmad 2016). According to $\mathrm{MOH}$, a cardiovascular disease is the number one cause of death since the early 1980s (MOH 2017). Diabetes mellitus (DM) has been found as one of the risk factors in developing ACS (Braun et al. 2018; Hewins 2016). Several previous studies reported that glycaemic disorder was an important risk factor of coronary plaque progression and instability, as well as subsequent ACS (Abadal \& Flores 2008; Deedwania et al. 2008; Wei \& Litwin 2014). Besides that, it is well documented that Statin medication itself, which is consumed by ACS patients, may cause Statin induced DM (Ford et al. 2016; Gasiorek 2016; Mach et al. 2018). Hence, this issue can lead to increased incidence of ACS. On the other hand, excessive body weight is also found to be one of the risk factors of ACS development (Koshizaka et al 2019).

Besides glucose control and body weight management, another solution for the problem is complementary or alternative medicine. This is a natural method that can be delivered to the ACS patients in order to promote treatments with no side effects in relation to glucose and body weight management.

\section{BACKGROUND}

Excessive serum glucose could lead to high cholesterol as glucose metabolism converts it to fat. In the condition of a high glucose level, the glucose that had been metabolised into fats would be deposited in the small arteries, leading to a disease known as arteriolosclerosis (Varghese \& Kumar 2019). Several previous studies have reported that glycaemic disorder is an important risk factor of coronary plaque progression and instability, as well as subsequent ACS (Abadal \& Flores 2008; Deedwania et al. 2008; Wei \& Litwin 2014). By introducing VCO, the substance can reduce the glucose level and body weight of patients. The serum glucose reduction could be due to the action of lauric acid (C12) present in VCO. Lauric acid is about $50 \%$ of the total VCO composition. Since no chemicals are used and there is little to no application of heat during its extraction, more natural active components are retained in VCO. This includes polyphenols which are proven to boost the antioxidant defence system.

An animal study conducted by Garfinkel et al. (1992), found that the effectiveness of medium-chain fatty acids (MCF) to stimulate insulin secretion was dependent upon its chain length. It was shown that adipic acid (C6), caprylic acid (C8), capric acid (C10), and lauric acid (C12) had varying effects. Meanwhile, adipic acid (C6) had no effect, caprylic acid (C8) had a minimal effect. Whereas, capric acid (C10) and lauric acid (C12) had very potent effects, a similar magnitude to the effect of linoleate on insulin secretion. Apart from blood glucose levels, excessive body weight is also considered as one of the risk factors of ACS. Body weight plays a central role in the pathway for both the development and treatment of type 2 diabetes. Three main risk factors for ACS, namely, hypertension, hypercholesterolemia, and diabetes mellitus, are all conditions that are strongly associated with obesity as well (Chapman \& Massey 1964; Stehben 1990; Wilson et al. 2002). Therefore, this study was conducted to evaluate and explore new innovative solutions to reduce the incidence of obesity and control the level of serum glucose among ACS patients.

\section{MATERIALS AND METHODS}

The aim of the study was to investigate the effect of VCO on glucose level, and body weight. This is a single-blinded randomized controlled trial. This is a unicenter, equal randomization with a ratio of $1: 1$ for parallel groups. The study was conducted in the medical cardiac ward of the University Malaya Medical Center (UMMC), Malaysia. The populations of interest were all subjects admitted to the cardiology clinic. Those who met the inclusion criteria and agreed to participate were recruited in this study. The recruitment criteria are as follows: ACS patient (this includes both STEMI and non-ST-segment elevation and unstable angina); patients' aged 25 to 65 years; both genders; patients with stable ACS with type 2 diabetic mellitus; and can understand Malay and English languages. Pregnant ladies, patients with uncontrolled hypothyroidism, patients with renal failure with creatinine $>2 \mathrm{mg} / \mathrm{dL}$, and patients with liver failure are not eligible for the study.

\section{SAMPLING METHOD}

Only subjects who meet the eligibility requirements are randomized into the study. After consent is obtained, block randomization (1:1) and random number table are used for the allocation of treatment. The sample size for the study is calculated based on the formula by Sakpal (2010). The sample size estimation during clinical trial with an 
alpha value of 0.05 , power of $80 \%$, clinically significant difference of 0.8 and a standard deviation of 0.74 are calculated based on the results of a previous study done by dela Paz et al. (2010).

A sample size of 100 participants, 50 in each arm is sufficient to detect a glucose level change $\mathrm{mmol} / \mathrm{L}$ of 0.5 within two groups with $80 \%$ power and $5 \%$ level of significance.

\section{DATA COLLECTION AND RANDOMIZATION}

The participants were obtained from the cardiac ward with the supervision and permission of the appointed PPUM Cardiologist. Eligible subjects were given the subject information sheet and consent form. The researcher then gave an explanation on the study procedure. The participants were given sufficient time to decide whether to participate or not in this study. They were free to withdraw from the study.

Initial screening in the ward was performed by the researchers. Participants were randomly assigned into the intervention group using simple random sampling. The intervention group continued the routine treatment and received VCO as additional treatment. The control group received the routine treatment and medication which included anti-diabetic medication such as subcutaneous insulin or Metformin. Each participant in the intervention group received three bottles, each labelled A, containing 100 pieces of soft gels. Label A is a code key for VCO soft gel. The participants were required to ingest 5 capsules of VCO twice per day $(0.5$ $\mathrm{mL} /$ capsule $=10$ capsules $/ 5 \mathrm{~mL}$ ) for 30 days. After 30 days, the researcher did a follow-up blood taking and body weight measurement to all the subjects in the ward. They were instructed to fast for at least $10 \mathrm{~h}$ before blood taking. They were instructed to return the empty label A containers and the amount left was measured in order to monitor the compliance.

This was a single blind study, in which the participants and medical laboratory technicians (outcome assessor) were not exposed with the code key. The VCO soft gels were provided by a local company. The company helped in preparing, packing, and distributing the soft gel VCO pills. In contrast, the control group received routine treatment such as attending CRP, continuing diabetes medications and diet control. All the participants remained on their medications throughout the experiment. No changes on medications were noted before, during, and after the experiment.

\section{ETHICAL CONSIDERATIONS}

The ethical committee approval was obtained from a medical research ethic committee from the University of
Malaya (reference number: 2017528-5276). The study has been registered under ANZCTR with the unique number; ACTRN12618001736235.

\section{RESULTS AND DISCUSSION}

The results of each randomized group were separately summarized based on baseline characteristics. An intention-to-treat (ITT) population was used for fulfilling primary outcomes, including all patients in the group to which they were randomized, irrespective of the size to which they were followed to the intervention. A per-protocol (PP) population was used for fulfilling secondary outcomes. Patients reported $>75 \%$ follow-up were included in the PP population. The researcher and a research assistant have conducted the recruitment process according to the CONSORT diagram (Figure 1). Only 71 individuals from 80 patients with ACS were invited and randomized for the baseline evaluation. On the $30^{\text {th }}$ day of follow up, 61 participants attended; 10 individuals were untraceable and two individuals did not attend the follow up due to disease progression. The total percentage of compliance was $86 \%$.

Table 1 shows the description characteristics for the participants. The overall mean age is 50 and two-thirds of the participants are male. Mean changes for the serum FBS on the $30^{\text {th }}$ day of follow up for each randomized group and a comparison between groups are shown in Table 2. Serum FBS concentrations were significantly reduced by $15.1 \%$ in the VCO group $(95 \% \mathrm{CI}-.19,0.33$, $\mathrm{p}<0.001$ ), from the baseline score to day 30 . Body weight has also showed significant reduction by $3.4 \%$ from the baseline score to day 30 . However, both serum FBS and body weight in the control group did not show any statistically significant difference from day 0 to 30 .

Over the period of 30 days, self-reported compliance was higher among $87 \%$ of patients in the intervention group, which was similar among the anti DM groups (86\%). As for feedback from the participants, 68\% reported feeling better in their daily activities and $22 \%$ reported feeling discomfort in consuming virgin coconut oil due to its oily odour and the slightly oily taste during eructation. Ten percent of the patients had reported stomach discomfort during the first two days of VCO consumption and symptom relief on the third day. The dietary intake levels of the baseline level for both groups were presented using a Nutrition analysis software (NUTRITICS). The total fat, protein, and carbohydrate intake did not differ between both groups. No changes in the type of regular physical activity have been reported by most participants. The regular physical activity increased by approximately 18 and $16 \%$ of the patients in both the VCO group and control group, respectively. 


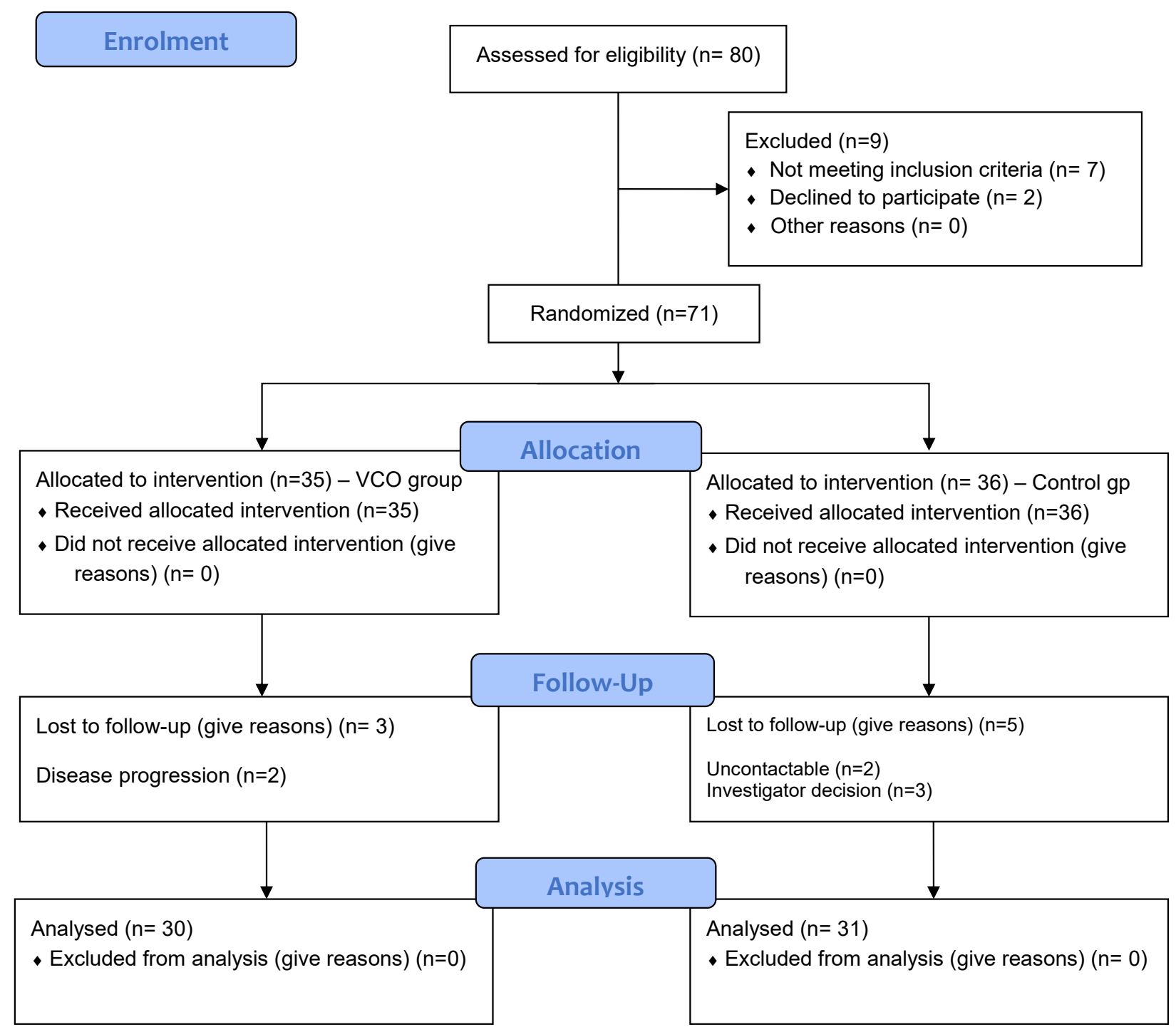

FIGURE 1. CONSORT Flow Diagram

\section{DISCUSSION}

In this study, middle-aged men and women, admitted in the cardiology unit in UUMC with ACS were randomly selected to consume $5 \mathrm{~mL}(5 \mathrm{~g})$ VCO per day along with the routine treatment and medications for 30 days. The control group only continued the routine treatment and medications without VCO. Statistically significant differences were reported in the serum glucose level between the two groups at the end of the trial. VCO also showed statistically significant difference in body weight reduction in VCO group and not in the control group.
This study opposed several previous studies which reported no effect of glucose during VCO consumption (Cardoso et al. 2015; Chinwong et al. 2017; Harris et al. 2017; Khaw et al. 2018; Liau et al. 2011). These studies have reported their findings on the effect of coconut oil instead of VCO. There are several differences between regular coconut oil and VCO. These differences include the process of extraction and the end product compositions of fatty acids. In general, the process of extracting coconut oil is done via bleaching and deodorizing processes, in which chemical agents are added, thus, causes the oil to lose a lot of its beneficial 
TABLE 1. Participants' characteristics

\begin{tabular}{|c|c|c|c|}
\hline Characteristic & $\begin{array}{l}\text { VCO group } \\
(\mathrm{n}=35) \\
\mathrm{M} \pm \mathrm{SD}\end{array}$ & $\begin{array}{l}\text { Control group } \\
\qquad \begin{array}{c}(\mathrm{n}=35) \\
\mathrm{M} \pm \mathrm{SD}\end{array}\end{array}$ & $P$ value \\
\hline Age (year) & $50.5 \pm 8.9$ & $53.8 \pm 10.1$ & $0.18^{\mathrm{a}}$ \\
\hline \multicolumn{4}{|l|}{ Gender } \\
\hline Male & 24 & 23 & \\
\hline Female & 11 & 12 & $0.10^{\mathrm{b}}$ \\
\hline \multicolumn{4}{|l|}{ Race } \\
\hline Malay & 18 & 16 & \\
\hline Chinese & 8 & 8 & $0.23^{\mathrm{b}}$ \\
\hline Indian & 9 & 11 & \\
\hline \multicolumn{4}{|l|}{ Education level } \\
\hline Tertiary & 17 & 16 & \\
\hline Secondary & 18 & 19 & $0.24^{\mathrm{b}}$ \\
\hline \multicolumn{4}{|l|}{ Marital status } \\
\hline Married & 30 & 32 & $061^{\mathrm{c}}$ \\
\hline Single & 5 & 3 & \\
\hline \multicolumn{4}{|l|}{ Diagnoses } \\
\hline Unstable angina & 14 & 16 & \\
\hline NSTEMI & 11 & 10 & $0.92^{\mathrm{b}}$ \\
\hline STEMI & 5 & 5 & \\
\hline \multicolumn{4}{|l|}{ Medications } \\
\hline Statin+ anticoagulant +Anti DM & 5 & 5 & \\
\hline Statin+Antihpt+Anti DMt + Anticoagulant & 25 & 26 & $0.98^{\mathrm{b}}$ \\
\hline Baseline Body Weight (kg) & $77.5 \pm 14.7$ & $74.1 \pm 10.5$ & $0.2^{\mathrm{a}}$ \\
\hline \multicolumn{4}{|l|}{ NUTRITICS (Nutrition analysis software) } \\
\hline Total calories & $2422 \pm(956.9)$ & $2367 \pm(784.6)$ & $0.91^{\mathrm{a}}$ \\
\hline Total energy kilojoules & $9941 \pm(4388)$ & $14519 \pm(2566)$ & $0.15^{\mathrm{a}}$ \\
\hline Protein $\%$ & $17.8 \pm(2.4)$ & $17.8 \pm(2.47)$ & $0.91^{\mathrm{a}}$ \\
\hline Carbohydrate \% & $56.9 \pm(5.2)$ & $50.5 \pm(6.5)$ & $0.45^{\mathrm{a}}$ \\
\hline Saturated fat $\%$ & $24.6 \pm(5.0)$ & $26.6 \pm(4.6)$ & $0.10^{\mathrm{a}}$ \\
\hline Alcohol \% & $0.6 \pm(1.5)$ & $1.1 \pm(2.0)$ & $0.72^{\mathrm{a}}$ \\
\hline \multicolumn{4}{|l|}{ Level of activities } \\
\hline - None - little or no regular exercise & 0 & 0 & \\
\hline - $\quad$ Light - 1-3 days per week & 14 & 13 & $0.92^{\mathrm{x}}$ \\
\hline - $\quad$ Moderate - 1-3 days light week or 5 days week hard & 11 & 12 & \\
\hline - Very active -6 days week hard & 6 & 6 & \\
\hline
\end{tabular}

Independent $\mathrm{t}$ test ${ }_{\mathrm{a}}$, Chi Square test ${ }_{\mathrm{b}}$, Fisher exact test ${ }_{\mathrm{c}}$ 
TABLE 2. Comparison between VCO group and control group for baseline data and day 30 (post intervention)

\begin{tabular}{|c|c|c|c|c|c|c|c|c|}
\hline \multirow{2}{*}{$\begin{array}{l}\text { Clinical parameter } \\
\text { Serum glucose }\end{array}$} & \multicolumn{3}{|c|}{ VCO group $(n=30)$} & \multicolumn{3}{|c|}{ Control group $(\mathrm{n}=31)$} & \multicolumn{2}{|c|}{$\begin{array}{c}\text { Comparison between } \\
\text { two groups }\end{array}$} \\
\hline & $\begin{array}{l}\text { Baseline } \\
\text { (Day 0) }\end{array}$ & (Day 30) & $* \mathrm{p}$ & $\begin{array}{l}\text { Baseline } \\
\text { (Day 0) }\end{array}$ & (Day 30) & $* p$ & $t(d f)$ & $* * \mathrm{p}$ \\
\hline Fasting blood sugar & $7.3 \pm 2.3$ & $6.31 \pm 1.95$ & 0.03 & $7.39 \pm 3.09$ & $8.31 \pm 3.45$ & 0.16 & $-2.7(59)$ & 0.00 \\
\hline Body weight & $77.5 \pm 14.7$ & $76 \pm 15.1$ & 0.00 & $68.3 \pm 13.6$ & $68.4 \pm 13.7$ & 0.24 & $2.54(59)$ & 0.05 \\
\hline
\end{tabular}

*Paired $\mathrm{t}$ test; ** Independent $\mathrm{t}$ test

fatty acids. Coconut oil does not show any beneficial contribution towards atherosclerosis and cardiovascular diseases, considering the presence of these properties. Whereas, VCO is extracted via a heat-free process such as fermentation, cold-press, and minimal heat exposure, and these processes retain all the important fatty acids that are beneficial for health. The process of extraction plays an important role in the reaction of oil towards the serum lipid profile. In addition, it could be the reason why some coconut oil studies seem to give harmful effects on health, particularly for lipid profiles.

In addition, in this study, VCO has shown beneficial effects in reducing serum fasting blood sugar with only $5 \mathrm{~mL}$ of $\mathrm{VCO}$ which contain $1.3 \mathrm{~g}$ of lauric acid, as compared to previous studies that used between 24 and $50 \mathrm{~g}$ of VCO. In this study, $1.3 \mathrm{~g}$ of lauric acid has significantly reduced the lipid profile. The VCO compositions are listed in Table 1. More than $50 \%$ of the total composition of VCO are fatty acids, which play a vital role in lowering the lipid profile. As reported by several previous studies, lauric acid helps to lower the lipid profile due to their action on rapid oxidation and less fat storage (Dayrit 2015; Li et al. 2018). Varying dosages of VCO can be an argument that needs to be highlighted as the cause why findings concerning the method appears to be inconsistent. Most likely, small dosages of lauric acid could be better for human body interaction in regard to serum glucose level.

In addition, the consumption of saturated fatty acids (SFA) including rich dietary vegetable oils such as coconut oil and palm oil has now been discouraged and the side effects of virgin coconut oil consumption have been reported. This is due to the belief that excess consumption of saturated fats for those with a diabetes mellitus condition can accelerate the atherosclerotic process. However, most recent investigations conducted on animals as well as human beings contradict such claims that coconut oil increases the risk of atherosclerosis and heart disease (Koshizaka et al 2019; Nevin \& Rajamohan 2004).

Even though lauric acid is categorized under saturated fats, but their chains fall under the medium chain triglyceride which result in direct oxidation and produce rapid energy. The transmission of lauric acid is reported directly into the liver in the form of energy and other metabolites. Ketone bodies are one of the types of these metabolites, which can be used by extrahepatic tissues in the form of energy (Tholstrup et al. 2004). This shows that synthetic MCT oil and dietary fats might have different physiological effects.

Due to different experimental doses, feeding periods and experimental designs, the findings of lauric acid on serum glucose level and body weight remain inconsistently observed.

This study has opposed the study by Liau et al. (2011), who found no differences in serum fasting blood glucose and body weight among 20 obese but healthy volunteers. They reported that there was no statically significant difference in glucose levels in VCO group from baseline until week four of the experiment. This could be due to the short duration of the study, causing the poor evaluation of VCO effects. Furthermore, Khaw et al. (2018) also reported that there was no significant difference between the baseline and follow-up data among participants who took VCO. In their study, the VCO group was instructed to take $50 \mathrm{~g}$ of VCO for 4 weeks and a comparison was made between the baseline and week four data. The insignificant result could be due to 
the high dosage of VCO consumed by the participants. As mentioned in the study by Jensen (1999) the calculation of recommended VCO was based on the amount of lauric acid found in a human mother's milk. The suggested daily intake of $24 \mathrm{~g}$ of lauric acid in an average adult is equivalent to $30 \mathrm{~mL}$ per day of VCO. The excessive intake of saturated fat may lead to increased cholesterol and glucose levels.

This study also reported on the significant reduction of the participants' body weight from the baseline to day 30 . As stated earlier, lauric acid can cause rapid oxidation and provide rapid energy. Hence, it can lead to satiation or the sensation of feeling full (Dayrit 2015). In principle, once individual oral intake is less, it will automatically reduce blood glucose in the body. When there is no glucose that needs to be metabolised in the body it will result in serum glucose levels to fall (Vallejo-Vaz et al. 2017). This is reflected on the participants' body weight where the VCO group body weight is reduced after 30 days consuming VCO. Apart from that, through simple conversation, the majority of VCO participants expressed the feeling of satiation after consuming VCO (Gasiorek 2016). In contrast, in a study by Liau et al. (2011), they reported that there were no changes in body weight among their 20 obese participants. This could be due to small number of samples; hence the study was unable to detect the difference. On top of that, the obese individuals that were selected as participants in the study may have difficulty in reducing body weight due to the physiology of fat in their body. A study by Longo et al. (2019) found that obese people have difficulty in reducing weight due to white adipose tissue (WAT) dysfunction. White adipose tissue may become severely dysfunctional and cannot expand properly to store the excess energy. This induces ectopic fat deposition in other tissues that regulates glucose homeostasis, an event commonly defined as 'lipotoxicity'. This mechanism leads to systemic insulin resistance and an increased risk of Type 2 Diabetes mellitus (Landgraf et al. 2015). Numerous adverse effects have been associated with the unhealthy expansion of the WAT. This includes inflammation, fibrosis, hypoxia, altered adipokines secretion, and mitochondrial dysfunction (Landgraf et al. 2015; Longo et al. 2019). Due to these unhealthy conditions, obese people are suffering 'fat tissue scarring' which may make it harder to lose weight.

\section{LIMITATIONS}

This pilot study applied the RCT design which served as the strength of the study. However, the short duration of study may cause an incomplete assessment of the VCO effects. Vigorous study designs with large samples are necessary in future research.

\section{CONCLUSION}

This study concludes that VCO is able to reduce serum glucose level and body weight with $5 \mathrm{~mL}(5 \mathrm{~g}) \mathrm{VCO}$ per day in 30 days. Consumption of VCO may have a positive effect towards glucose levels and other cardiovascular risk factors.

\section{ACKNOWLEDGEMENTS}

This work was supported by the Smartfund Research Fund (Grant no. SR1217Q1043). The authors would like to thank the volunteers for their participation.

\section{REFERENCES}

Abadal, A.C. \& Flores, J.S. 2008. The significance of hyperglycemia in acute coronary. Revista Española de Cardiología 61(5): 447-450.

Ahmad, W.A.W. 2016. Annual Report of the NCVD-PCI Registry Year 2015-2016. Malaysia: National Cardiovascular Disease Database.

Barstow, C., Rice, M.S. \& McDivitt, J.D. 2017. Acute coronary syndrome: Diagnostic evaluation. American Family Physician 95(3): 170-177.

Braun, M.M., William, A.S. \& Craig, H.B. 2018. Stable coronary artery disease: Treatment. American Family Physician 97(6) 376-384.

Cardoso, D.A., Moreira, A.S., de Oliveira, G.M., Luiz, R.R. \& Rosa, G. 2015. A coconut extra virgin oil-rich diet increases HDL cholesterol and decreases waist circumference and body mass in coronary artery disease patients. Nutricion Hospitalaria 32(5): 2144-2152.

Chapman, J.M. \& Massey Jr., F.J. 1964. The interrelationship of serum cholesterol, hypertension, body weight, and risk of coronary disease: results of the first ten years' follow-up in the Los Angeles heart study. Journal of Chronic Diseases 17(10): 933-949.

Chinwong, S., Chinwong, D. \& Mangklabruks, A. 2017. Daily consumption of virgin coconut oil increases high-density lipoprotein cholesterol levels in healthy volunteers: A randomized crossover trial. Evidence-Based Complementary and Alternative Medicine 2017: 7251562.

Dayrit, F.M. 2015. The properties of lauric acid and their significance in coconut oil. Journal of the American Oil Chemists'Society 92(1): 1-15.

Deedwania, P., Kosiborod, M., Barrett, E., Ceriello, A., Isley, W., Mazzone, T. \& Raskin, P. 2008. Hyperglycemia and acute coronary syndrome: A scientific statement from the American Heart Association Diabetes committee of the council on nutrition, physical activity, and metabolism. Circulation 
117(12): 1610-1619.

dela Paz, C., Jimeno, C., Sy, R., Eduardo, F., Punzalan, M.D. $\&$ dela Pena, P. 2010. The effect of virgin coconut oil on lipid profile and fasting blood sugar: A phase I clinical trial. Philippine Journal of Internal Medicine 48(2). doi. org/10.3860/PJIM.V48I2.2632.

Ford, I., Murray, H., McCowan, C. \& Packard, C.J. 2016. Longterm safety and efficacy of lowering low-density lipoprotein cholesterol with statin therapy: 20-year follow-up of west of Scotland coronary prevention study. Circulation 133(11): 1073-1080.

Gasiorek, J. 2016. The "dark side" of CAT. In Communication Accommodation Theory: Negotiating Personal Relationships and Social Identities Across Contexts, edited by Giles, H. Cambridge: Cambridge University Press. pp. 85-104.

Garfinkel, M., Lee, S., Opara, E.C. \& Akwari, O.E. 1992. Insulinotropic potency of lauric acid: A metabolic rationale for medium chain fatty acids (MCF) in TPN formulation. Journal of Surgical Research 52(4): 328-333.

Harris, M., Hutchins, A. \& Fryda, L. 2017. The impact of virgin coconut oil and high-oleic safflower oil on body composition, lipids, and inflammatory markers in postmenopausal women. Journal of Medicinal Food 20(4): 345-351.

Hewins, K. 2016. 2014 NSTE-ACS Guidelines Overview. In Acute Coronary Syndrome Summit.

Jensen, R.G. 1999. Lipids in human milk. Lipids 34(12): 12431271.

Khaw, K.T., Sharp, S.J., Finikarides, L., Afzal, I., Lentjes, M., Luben, R. \& Forouhi, N.G. 2018. Randomised trial of coconut oil, olive oil or butter on blood lipids and other cardiovascular risk factors in healthy men and women. $B M J$ Open 8(3): p.e020167.

Koshizaka, M., Ishikawa, K., Ishibashi, R., Maezawa, Y., Sakamoto, K., Uchida, D., Nakamura, S., Yamaga, M., Yokoh, H., Kobayashi, A. \& Onishi, S. 2019. Comparing the effects of ipragliflozin versus metformin on visceral fat reduction and metabolic dysfunction in Japanese patients with type 2 diabetes treated with sitagliptin: A prospective, multicentre, open-label, blinded-endpoint, randomized controlled study (PRIME-V study). Diabetes, Obesity and Metabolism 21(8): 1990-1995.

Landgraf, K., Rockstroh, D., Wagner, I.V., Weise, S., Tauscher, R., Schwartze, J.T., Löffler, D., Bühligen, U., Wojan, M., Till, H. \& Kratzsch, J. 2015. Evidence of early alterations in adipose tissue biology and function and its association with obesity-related inflammation and insulin resistance in children. Diabetes 64(4): 1249-1261.

Li, H., Liu, Y., Zhang, X., Xu, Q., Zhang, Y., Xue, C. \& Guo, C. 2018. Medium-chain fatty acids decrease serum cholesterol via reduction of intestinal bile acid reabsorption in C57BL/6J mice. Nutrition \& Metabolism 15(1): 1-12.

Liau, K.M., Lee, Y.Y., Chen, C.K. \& Rasool, A.H.G. 2011. An open-label pilot study to assess the efficacy and safety of virgin coconut oil in reducing visceral adiposity. ISRN
Pharmacology 2011: 949686

Longo, M., Zatterale, F., Naderi, J., Parrillo, L., Formisano, P., Raciti, G.A., Beguinot, F. \& Miele, C. 2019. Adipose tissue dysfunction as determinant of obesity-associated metabolic complications. International Journal of Molecular Sciences 20(9): 2358.

Mach, F., Ray, K.K., Wiklund, O., Corsini, A., Catapano, A.L., Bruckert, E., De Backer, G., Hegele, R.A., Hovingh, G.K., Jacobson, T.A. \& Krauss, R.M. 2018. Adverse effects of statin therapy: perception vs. the evidence-focus on glucose homeostasis, cognitive, renal and hepatic function, haemorrhagic stroke and cataract. European Heart Journal 39(27): 2526-2539.

MOH. 2015. Health Facts 2015. Malaysia: Ministry of Health Malaysia (MOH).

MOH. 2017. Primary \& Secondary Prevention of Cardiovascular Disease 2017. Malaysia: Ministry of Health Malaysia (MOH).

Nevin, K.G. \& Rajamohan, T. 2004. Beneficial effects of virgin coconut oil on lipid parameters and in vitro LDL oxidation. Clinical Biochemistry 37(9): 830-835.

Stehbens, W.E. 1990. The epidemiological relationship of hypercholesterolemia, hypertension, diabetes mellitus and obesity to coronary heart disease and atherogenesis. Journal of Clinical Epidemiology 43(8): 733-741.

Tholstrup, T., Ehnholm, C., Jauhiainen, M., Petersen, M., Høy, C.E., Lund, P. \& Sandström, B. 2004. Effects of mediumchain fatty acids and oleic acid on blood lipids, lipoproteins, glucose, insulin, and lipid transfer protein activities. The American Journal of Clinical Nutrition 79(4): 564-569.

Vallejo-Vaz, A.J., Robertson, M., Catapano, A.L., Watts, G.F., Kastelein, J.J., Packard, C.J., Ford, I. \& Ray, K.K. 2017. Low-density lipoprotein cholesterol lowering for the primary prevention of cardiovascular disease among men with primary elevations of low-density lipoprotein cholesterol levels of $190 \mathrm{mg} / \mathrm{dL}$ or above: Analyses from the WOSCOPS (West of Scotland coronary prevention study) 5-year randomized trial and 20-year observational follow-up. Circulation 136(20): 1878-1891.

Varghese, T.P. \& Kumar, A.V. 2019. Predisposing risk factors of acute coronary syndrome (ACS): A mini review. Journal of Pharmaceutical Sciences and Research 11(5): 1999-2002.

Wei, C.H. \& Litwin, S.E. 2014. Hyperglycemia and adverse outcomes in acute coronary syndromes: Is serum glucose the provocateur or innocent bystander? Diabetes 63(7): 2209-2212.

Wilson, P.W., D’Agostino, R.B., Sullivan, L., Parise, H. \& Kannel, W.B. 2002. Overweight and obesity as determinants of cardiovascular risk: The Framingham experience. Archives of Internal Medicine 162(16): 1867-1872.

Sharifah Shafinaz binti Sh Abdullah \& Mei Chan Chong* Nursing Department, Faculty of Medicine University of Malaya

Jalan Universiti

50603 Kuala Lumpur, Wilayah Persekutuan 
Malaysia

Khatijah Lim Abdullah

Department of Nursing

School of Medical and Life Sciences

Sunway University, Jalan Universiti

Bandar Sunway

47500 Petaling Jaya, Selangor Darul Ehsan

Malaysia

Sharifah Shafinaz binti Sh Abdullah \& Imran Zainal Abidin Medical Department, Faculty of Medicine

University of Malaya

Jalan Universiti

50603 Kuala Lumpur, Wilayah Persekutuan

Malaysia
Bee Wah Yap

Faculty of Computer and Mathematical Sciences

Universiti Teknologi MARA

40450 Shah Alam, Selangor Darul Ehsan

Malaysia

*Corresponding author; email: mcchong@um.edu.my

Received: 1 May 2020

Accepted: 24 March 2021 